\title{
Soil and vegetation carbon pools in two community forests of Palpa district, Nepal
}

\author{
Y. Khanal ${ }^{1}$, R. P. Sharma ${ }^{2}$ and C. P. Upadhyaya ${ }^{3}$
}

\begin{abstract}
Quantification of carbon in any vegetation and soil type is a basic step for evaluating the carbon sequestration potential of an ecosystem. For quantification, soil samples from varying depths $(0-20,20-40,40-60,60-80$ and $80-100 \mathrm{~cm})$ of each soil profile were collected for each sample plot laid out in Jarneldhara and Lipindevi Thulopakho Community Forests (CFs) of Palpa district. Individual trees in the sample plots of both CFs were measured. Biomass of standing trees, poles and saplings were estimated indirectly from diameter at breast height (dbh) and total height by using allometric relationships, while the biomass of grass, herb and litter were calculated directly from field measurements. Above-ground and below-ground (root) carbon pools in Jarneldhara CF were found to be $36.6 \pm 3.4 \mathrm{t} \mathrm{ha}^{-1}$ and $10.5 \pm 1.0 \mathrm{t} \mathrm{ha}^{-1}$, respectively; while those on Lipindevi Thulopakho CF were $40.2 \pm 4$ and $11.4 \pm 1.1 \mathrm{t} \mathrm{ha}^{-1}$, respectively. Soil organic carbon pool in Jarneldhara and Lipindevi Thulopakho CF were $121.4 \pm 7.4$ and $94.6 \pm$ $4.4 \mathrm{t} \mathrm{ha}^{-1}$, respectively. This indicates that CFs have high potential to offset large portion of carbon emission through sequestration into both soil and vegetation, and act as a natural carbon sink.
\end{abstract}

Key words: Carbon pool, community forest, soil organic carbon, vegetation carbon, biomass

$\mathbf{F}$ orest plays a key role in the global and regional carbon (C) cycles, as they store large quantities of $\mathrm{C}$ in vegetation and soil, and exchange large quantities of $\mathrm{C}$ with atmosphere through photosynthesis and respiration. Forest acts as a source of atmospheric $\mathrm{C}$ when there is disturbance due to anthropogenic and natural causes and as a sink when re-growth occurs after disturbance, therefore, forest can be managed to alter the magnitude and direction of fluxes (Brown, et al., 1996). The goal of reducing $C$ source and increasing $\mathrm{C}$ sink can be achieved through effective protection and conservation of $\mathrm{C}$ pools in the existing forest.

The Kyoto protocol of the United Nations Framework Convention on Climate Change (UNFCCC) has recognized the role of forestry as a reliable carbon sequestration vehicle to reduce green house gas in the atmosphere. After the UNFCCC conference of parties in Bali, Indonesia during December, 2007, the debate and discussion on Reducing Emission from Deforestation and Forest
Degradation (REDD) has emerged. This has created a good opportunity for studying $\mathrm{C}$ pools in forest ecosystem.

Vegetation and soil are viable sinks of atmospheric $\mathrm{C}$ and may significantly contribute to the mitigation of global climate change (Lal, 2004; Smith, 2004). Carbon sequestration in terrestrial ecosystems, especially into the soil, is a win-win strategy for developing countries, where land use change and agricultural intensification are most frequent (Lal, 2004). To quantify the sequestered $C$ in forest ecosystem, temporal stocks of $\mathrm{C}$ under various forest types must be assessed. Estimating $\mathrm{C}$ pools in existing forests provides baseline data from which to project C sequestration over time (Shrestha and Singh, 2008).

Biological sequestration of $\mathrm{CO}_{2}$ by forest has numerous benefits over other emission reduction strategies. First, it is considered the most costeffective approach (e.g. Newell and Stavins, 2000; Stern, 2007; Banskota et al., 2008). Second, managing

\footnotetext{
Far-Western Regional Forest Directorate, Dhangadhi. Email: yajnamurti@hotmail.com

2 Department of Ecology and Natural Resource Management, Norwegian University of Life Sciences, Norway

3 Institute of Forestry, Pokhara
} 
forests in a sustainable way, especially in the tropical region, can substantially reduce $\mathrm{C}$ emission rate. For example, it was estimated that the global deforestation alone accounts for about $17.4 \%$ of the global greenhouse gas emission (IPCC, 2007). Third, terrestrial ecosystems have the potential to store large amount of carbon due to high global deforestation rate in the past (Upadhyay et al., 2005). Thus, it seems that forest could be the most effective sink when forest is protected and managed in a sustainable way, and a huge amount of $\mathrm{C}$ is sequestered efficiently without requirement of large monetary investment.

Quantification of sequestered C in different forest types with different management regimes and soil profiles could be important for better planning of natural resources, and the making of good mitigation strategy for climate change effects. However, so far only a few studies on $\mathrm{C}$ sequestration have been carried out in Nepal (Shrestha and Singh, 2008). Most studies focused on carbon stocks in different land uses (e.g., Gautam, 2002; Shrestha and Singh, 2008). Similarly, few studies were focused only on organic carbon stocks in different forest soils of Nepal (e.g., Awasthi et al., 2002; Shrestha et al., 2004a; Sitaula et al., 2004). Carbon sequestration potential of different forest types under different management regimes need to be explored. This study aims to quantify forest biomass, with both soil and vegetation $\mathrm{C}$ pools in two different CFs in a mid-hill region of Nepal.

\section{Materials and methods}

\section{Study area}

This study was carried out in Lipindevi Thulopakho and Jarneldhara community forests of Palpa district (Fig 1). Lipindevi Thulopakho CF is located in Tansen Municipality-13 whereas Jarneldhara CF is in Barangdi VDC Ward Number 3. The area of Lipindevi Thulopakho CF is 26.23 and that of Jarneldhara CF is 8.6 ha. They were handed over to the forest user communities in 1991 and 1994 A.D., respectively. Both CFs were situated on moderate to steep slopes with altitude ranging from $1100-1400$ $\mathrm{m}$ above mean sea level. Jarneldhara CF mostly lies on northern aspect whereas Lipindevi Thulopakho CF lies on the north-eastern aspect. The soil type varies from sandy loam to clay loam and is mostly brown in colour. The average maximum and minimum temperature of the district was $23{ }^{\circ} \mathrm{C}$ and $14^{\circ} \mathrm{C}$ with a mean annual rainfall of $1903 \mathrm{~mm}$ (DFOPalpa, 2007). Lipindevi Thulopakho CF consists of scattered plantation of Pinus roxburghii along with natural Schima-Castanopsis forest whereas Jarneldhara CF mainly consists of natural Schima-Castanopsis forest.

According to forest users, the age of SchimaCastanopsis forest stands is about 10-15 years whereas Pinus roxburghii is $20-25$ years. Average crown cover of the forest is about 40-60\%. The major management activities undertaken in both $\mathrm{CF}$ were cleaning, bush land management, thinning, pruning and improvement felling. In addition to these, firelines were constructed in Lipindevi Thulopakho CF. Similarly, on some blocks of Lipindevi Thulopakho $\mathrm{CF}$, up to three thinning operations have been carried out after the handing over of CF.

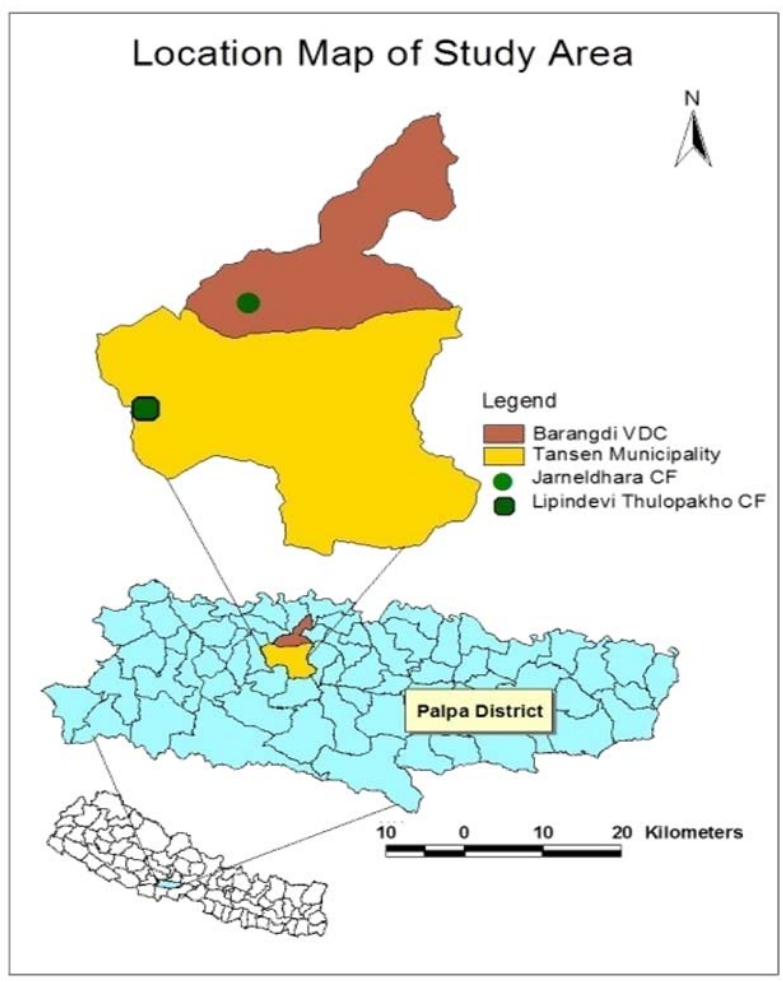

Fig 1: Study area in Palpa, Nepal

\section{Data collection and analysis}

\section{Forest sampling and measurement}

The studied CFs mainly consists of Schima-Castanopsis forest with varying tree size, density and species composition. In Lipindevi Thulopakho CF, there were also scattered plantations of Pinus roxburghii. So, in order to represent all variations, approximately $2-3 \%$ sample of forest area was selected subjectively from each community forest. Temporary plots were laid out in each selected forest type. Within the main plot with size $25 \mathrm{~m} \times 20 \mathrm{~m}$ for trees \{diameter at breast height $(\mathrm{dbh})>30 \mathrm{~cm}\}$, nested plots of size 
$10 \mathrm{~m}$ x $10 \mathrm{~m}$ for poles (dbh $<10-30 \mathrm{~cm}), 5 \mathrm{~m}$ x $5 \mathrm{~m}$ for saplings (dbh 5-10 cm) were laid out (CFD, 2004). Similarly, five $1 \mathrm{~m}$ x $1 \mathrm{~m}$ plots within the main plots (four in four corners and one at centre) were also laid out for regeneration $(\mathrm{dbh}<5 \mathrm{~cm})$, grasses, herbs and litters.

The dbh and total height of all trees, poles and saplings above $5 \mathrm{~cm}$ dbh were measured. All herbaceous and woody vegetations (less than $5 \mathrm{~cm}$ $\mathrm{dbh}$ ) inside the $1 \mathrm{~m} \times 1 \mathrm{~m}$ plot were clipped and collected and the fresh weight of the samples were recorded and representative sub-samples of all woody, herbaceous plants and litters were taken to the laboratory for oven drying.

\section{Biomass and carbon estimation}

Based on the data of tree height and dbh measured for individual stands within the sample plot, total stem volume was calculated using the following relationship models (Sharma and Pukkala, 1990).

$\ln (\mathrm{V})=\mathrm{a}+\mathrm{b} * \ln (\mathrm{dbh})+\mathrm{c} * \ln (\mathrm{ht})$

Where, $V$ is the total stem volume with bark $\left(m^{3}\right)$, $d b b$ is the diameter at the breast height $(\mathrm{cm}), h t$ is total tree height $(m)$, and $a, b$, and $c$ are species specific model parameters. The species-specific parameter values of model (1) are presented in Table 1.

\section{Table 1: Species-specific parameter estimates for model (1) (Sharma and Pukkala, 1990)}

\begin{tabular}{lccc}
\hline Tree species & a & b & c \\
\hline Alder (Alnus nepalensis) & -2.7761 & 1.9006 & 0.9428 \\
Chirpine (Pinus roxburgbii) & -2.9770 & 1.9235 & 1.0019 \\
Chilaune (Schima wallichii) & -2.7385 & 1.8155 & 1.0072 \\
Miscellaneous in Hills & -2.3204 & 1.8507 & 0.8223 \\
\hline
\end{tabular}

The total stem volume obtained from (1) was multiplied with species-specific dry wood density to get the oven dry weight of stem biomass. The biomass of branches, roots and leaves were assumed to be $45 \%, 46 \%$ and $11 \%$ of the stem biomass following Sharma (2003), which was later adopted by Shrestha and Singh (2008) for forest types identical to those in this study. Samples of undergrowth vegetation (tree species with $\mathrm{dbh}<5 \mathrm{~cm}$, herbs, grasses and litter) were oven dried at a constant temperature of $70^{\circ} \mathrm{C}$ until the weights of the samples became constant (MacDicken, 1997) and the final constant weight was used as dry matter content. Dry biomass was converted to $\mathrm{C}$ content using an assumption that $\mathrm{C}$ content is approximately $43 \%$ of dry biomass (Negi et al., 2003).

\section{Sampling soil and estimating soil carbon content}

A pit was made in the centre of each main plot with a maximum depth of $1 \mathrm{~m}$ or up to bedrock if it occurs at less than $1 \mathrm{~m}$ depth. If bedrock was present above $40 \mathrm{~cm}$ depth, the pit was dug in one corner of main plot. Soil samples were collected from different depths such as $0-20 \mathrm{~cm}, 20-40 \mathrm{~cm}, 40-60 \mathrm{~cm}, 60-80$ $\mathrm{cm}$ and $80-100 \mathrm{~cm}$ for carbon content analysis. Similarly, metal core ring sampler (height $6 \mathrm{~cm}$ and inner diameter $4.8 \mathrm{~cm}$ ) was used to collect samples for bulk density.

Soil Organic Carbon (SOC) content in the soil samples were estimated using Walkley and Black's wet oxidation method as described by Page et al. (1982). Soil $\mathrm{pH}$ was determined with $\mathrm{pH}$ electrode at soil/water ratio of 1:1 (w/w) (McLean, 1982). Soil bulk density was determined using soil core samples and stone correction was made as per Pearson et al. (2005). The corrected bulk density $\left(\mathrm{g} \mathrm{cm}^{-3}\right)$ was used for the estimation of SOC density $\left(\mathrm{t} \mathrm{ha}^{-1}\right)$ and SOC stock (Pearson et al., 2005).

Bulk density $\left(\mathrm{g} \mathrm{cm}^{-3}\right)$ denotes soil particles less than $2 \mathrm{~mm}$ diameter whereas coarse fragments include particles greater than $2 \mathrm{~mm}$ diameter. The oven dry mass and mass of coarse fragments were measured in gram $(\mathrm{g})$ and the volume of the cores in cubic centimetre $\left(\mathrm{cm}^{3}\right)$. The density of rock fragments was assumed to be $2.65 \mathrm{~g} \mathrm{~cm}^{-3}$ (Pearson et al., 2005).

\section{Results and discussion}

\section{Vegetation carbon pool Carbon pool in above-ground vegetation}

Biomass of trees varies in different plots of same forest and within different forests due to variation in age and size of the trees, forest composition as well as tree density. The mean above-ground tree biomass in Lipindevi Thulopakho CF was found to be $89.7 \pm 8.9 \mathrm{t} \mathrm{ha}^{-1}$ (Mean $\pm \mathrm{SE}$ ) which was higher than in Jarneldhara CF $\left(82.6 \pm 7.8 \mathrm{t} \mathrm{ha}^{-1}\right)$ (Table 2). Similarly, under-growth (live and dead) biomass of Lipindevi Thulopakho CF was found to be higher than that of Jarneldhara CF (Table 2), however, biomass difference was not significant $(\mathrm{P}>0.05)$. The share of under-growth biomass was only about $3 \%$ 
of the total above-ground biomass. The undergrowth biomass consisted mainly of litter biomass (by 65\%) followed by biomass of regeneration $(<5$ $\mathrm{cm} \mathrm{dbh}$ ) trees and grass.

Table 2: Vegetation biomass (Mean $\pm \mathrm{SE}, \mathrm{t} \mathrm{ha}^{-1}$ )

\begin{tabular}{lccc}
\hline CF & $\begin{array}{c}\text { Above ground } \\
\text { Tree }\end{array}$ & $\begin{array}{c}\text { Under-growth } \\
\text { (live \&dead) }\end{array}$ & $\begin{array}{c}\text { Below ground } \\
\text { (root) }\end{array}$ \\
\hline Jarneldhara & $82.6 \pm 7.8$ & $2.5 \pm 0.2$ & $24.4 \pm 2.3$ \\
Lipindevi & $89.7 \pm 8.9$ & $3.9 \pm 0.3$ & $26.5 \pm 2.6$ \\
Thulopakho & & & \\
\hline
\end{tabular}

Above-ground carbon pool (both tree and undergrowth) in Lipindevi Thulopakho CF (40.2 \pm $4 \mathrm{t} \mathrm{ha}^{-1}$ ) was found to be slightly higher than Jarneldhara CF (Table 3) due to larger sized trees which consequently have higher biomass values. Carbon pool in above-ground tree biomass was 33 times larger than the carbon pool in the under-growth biomass in Jarneldhara CF whereas it was 24 times larger in Lipindevi Thulopakho CF.

Various factors affect ecosystem carbon pool, including net primary productivity of plants and biomass decomposition. Net primary productivity differs according to vegetation types, age of the stand and the surrounding environment (Shrestha and Singh, 2008). This study suggests that larger Table 3: Vegetation carbon (Mean $\pm \mathrm{SE}, \mathrm{t} \mathrm{ha}^{-1}$ )

\begin{tabular}{lccc}
\hline CF & $\begin{array}{c}\text { Above ground } \\
\text { Tree }\end{array}$ & $\begin{array}{c}\text { Under-growth } \\
\text { (live \&dead) }\end{array}$ & $\begin{array}{c}\text { Below ground } \\
\text { (root) }\end{array}$ \\
\hline Jarneldhara & $35.5 \pm 3.4$ & $1.1 \pm 0.1$ & $10.5 \pm 1.0$ \\
Lipindevi & $38.6 \pm 3.9$ & $1.6 \pm 0.1$ & $11.4 \pm 1.1$ \\
Thulopakho & & & \\
\hline
\end{tabular}

vegetation carbon pool in Lipindevi Thulopakho CF than Jarneldhara CF is probably a function of the age and density of the stands and size of the trees. Shrestha and Singh (2008), Oli and Shrestha (2009), Shrestha (2009) and Baral et al. (2009) found more or less similar above-ground carbon pools in the midhill forests.

\section{Root carbon pool}

Root biomass of two CFs is shown in Table 2. Root biomass of Lipindevi Thulopakho CF was found to be $26.45 \pm 2.6 \mathrm{t} \mathrm{ha}^{-1}$ which was higher than that of Jarneldhara CF. Since the stem biomass of Lipindevi Thulopakho CF was higher than that of Jarneldhara $\mathrm{CF}$, root biomass was also higher in Lipindevi Thulopakho CF.

Carbon pool in root biomass is shown in Table 3. Below-ground vegetation (root) carbon of Lipindevi Thulopakho CF was found to be $11.4 \pm 1.1 \mathrm{t} \mathrm{ha}^{-1}$ which was slightly higher than Jarneldhara CF. Shrestha (2009) found similar root carbon pools in the community managed Schima-Castanopsis forests of Palpa district.

\section{Soil carbon pool Soil properties}

The soil was sandy loam with varying proportions of clay. The mean $\mathrm{pH}$ of surface soil (0-20 cm depth) of Jarneldhara CF was found to be 4.3 while that of Lipindevi Thulopakho CF was 4.6. This suggests that all soil types were acidic a pattern noted by Schreier et al. (1995) for soils in the mid-hill watersheds.

Mean soil Bulk Density (BD) at different soil depth is shown in Fig 2. Mean BD value ranged from 0.88 $\mathrm{g} \mathrm{cm}^{-3}$ to $1.07 \mathrm{~g} \mathrm{~cm}^{-3}$. The mean BD increased slightly with increasing soil depth, but it did not differ significantly across layers of the soil profile ( $p>0.05)$. Shrestha et al. (2004b) in their study of similar forest types of Mardi watershed of Kaski, Nepal found relatively low BD with constant value of $0.7 \mathrm{~g} \mathrm{~cm}^{-3}$ in each layer of soil up to $40 \mathrm{~cm}$ depth. However, Shrestha and Singh (2008) found slightly higher BD values than those in this study in similar forest types of the mid-hills. Shrestha (2009) found similar bulk density values for Schima-Castanopsis forest in Palpa district.

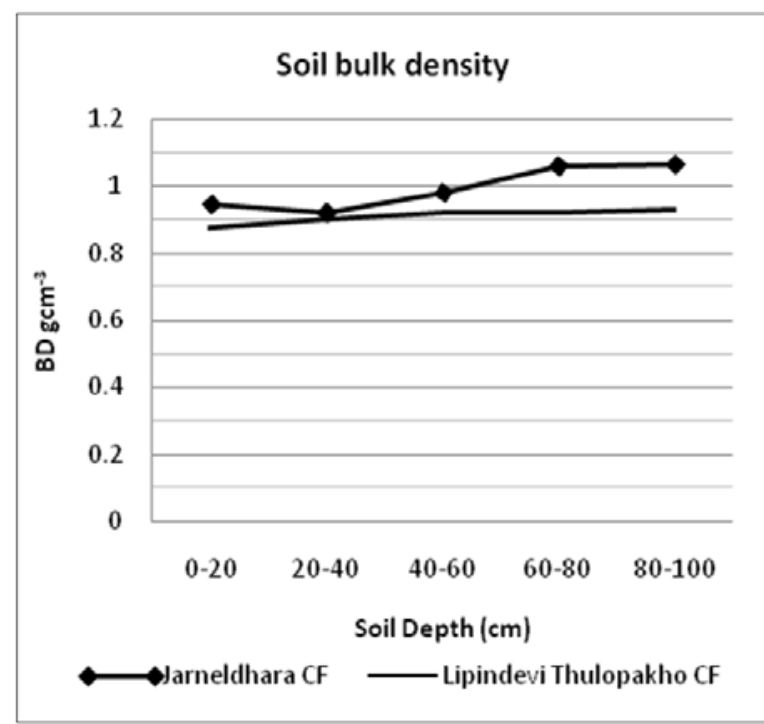

Fig 2: Soil bulk density in different soil depth

\section{Soil organic carbon}

Soil organic carbon pool in different soil profiles of each CF is shown in Table 4. Carbon content was found to be inversely related with increasing soil depth. Total mean carbon pool in the surface soil $(0-20 \mathrm{~cm})$ of Jarneldhara CF was found to be highest 
$\left(52.3 \pm 3 \mathrm{t} \mathrm{ha}^{-1}\right)$; the lowest mean carbon pool was found in the deepest soil layer $(80 \mathrm{~cm}-100 \mathrm{~cm})$ of Lipindevi Thulopakho CF (11.6 $\left.\pm 0.5 \mathrm{t} \mathrm{ha}^{-1}\right)$. Carbon pool in each layer of soil profile differed significantly in both the CFs $(\mathrm{p}<0.05)$. Mean carbon pool in each soil layer of both the CFs also differed significantly $(p<0.05)$. The results indicated that with increase in soil depth, bulk density was found to be in increasing trend while the SOC was found to be in decreasing trend. Almost similar results were obtained by Shrestha (2009).

\section{Table 4: Carbon stock in different soil profile}

\begin{tabular}{lll}
\hline \multirow{2}{*}{$\begin{array}{l}\text { Soil depth } \\
(\mathrm{cm})\end{array}$} & \multicolumn{2}{c}{ Organic carbon $\left(\right.$ Mean $\left.\pm \mathrm{SE}, \mathrm{t} \mathrm{ha}^{-1}\right)$} \\
\cline { 2 - 3 } $0-20$ & Jarneldhara CF & \multicolumn{1}{c}{ Lipindevi Thulopakho CF } \\
\cline { 2 - 3 } $20-40$ & $32.5 \pm 3.0$ & $31.6 \pm 2.0$ \\
$40-60$ & $27.5 \pm 1.4$ & $21.8 \pm 1.3$ \\
$60-80$ & $30.7 \pm 0.2$ & $13.9 \pm 0.6$ \\
$80-100$ & $19.5 \pm 2.7$ & $11.6 \pm 0.5$ \\
\hline
\end{tabular}

Amount of soil organic carbon depends upon various biotic and abiotic factors such as microclimate, faunal diversity, land use and management. Leaf litter and root litter inputs play major roles in forest soil carbon dynamics (Shrestha and Singh, 2008). The soil organic carbon pool in this study was comparable to the soil organic carbon pool values reported by Shrestha and Singh (2008) and Shrestha (2009). Shrestha and Singh (2008) in their study (up to $70 \mathrm{~cm}$ soil depth) in the mid-hill watershed found SOC density as $103 \mathrm{t} \mathrm{ha}^{-1}$ whereas Shrestha (2009) found slightly higher SOC density as $131.43 \mathrm{t} \mathrm{ha}^{-1}$ (up to $1 \mathrm{~m}$ soil depth) than that found in this study (121.3 $\mathrm{t} \mathrm{ha}^{-1}$ up to $1 \mathrm{~m}$ soil depth) for Schima-Castanopsis forest.

\section{Total carbon pool}

Total carbon pool in the two community forests is shown in Figure 3. The mean carbon pool (soil plus vegetation) in Jarneldhara CF was slightly higher than that in Lipindevi Thulopakho CF, although vegetation carbon pool was found to be higher in Lipindevi Thulopakho CF. Due to the presence of large-size trees in Lipindevi Thulopakho CF, there was higher vegetation carbon pool compared to Jarneldhara CF. Similarly, higher soil bulk density and organic carbon content in the soil of Jarneldhara CF has resulted in the higher soil carbon pool. Low soil carbon pool in Lipindevi Thulopakho CF was also attributed to the presence of Chir pine (Pinus roxburghii) trees which attract frequent forest fire due to longer decomposition period of their needles. Every year, there are occurrences of forest fires in Lipindevi Thulopakho CF which could be a possible reason for low carbon content in its soil. Shrestha and Singh (2008) also found lower soil carbon pool in pine mixed forest than in other forest types.

The mean of the total carbon pool from the two CFs is comparable to that of Shrestha and Singh (2008) and Shrestha (2009) in Schima-Castanopsis forest in the mid hills of Nepal. Shrestha and Singh (2008) reported total carbon pool (vegetation plus soil) of $139 \mathrm{t} \mathrm{ha}^{-1}$, which was slightly lower than that found in this study, which might be due to the use of soil carbon up to $70 \mathrm{~cm}$ soil depth in their study, as well as the difference in site quality and stand structure.

\section{Total carbon: $168.48 \mathrm{t} \mathrm{ha}{ }^{-1}$}

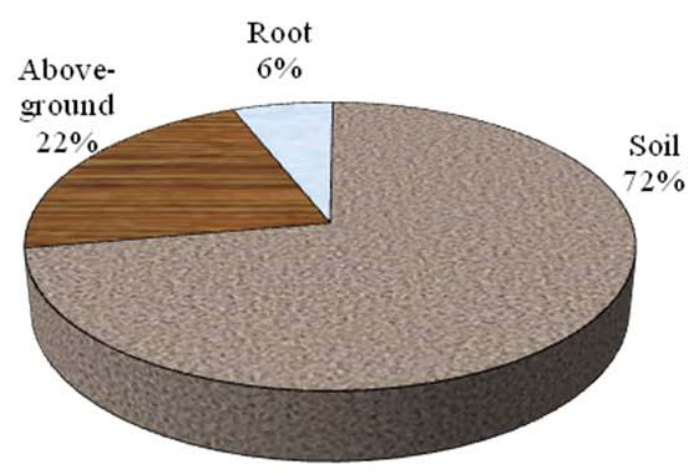

Jarneldhara CF

\section{Total carbon: $146.16 \mathrm{t} \mathrm{ha}^{-1}$}

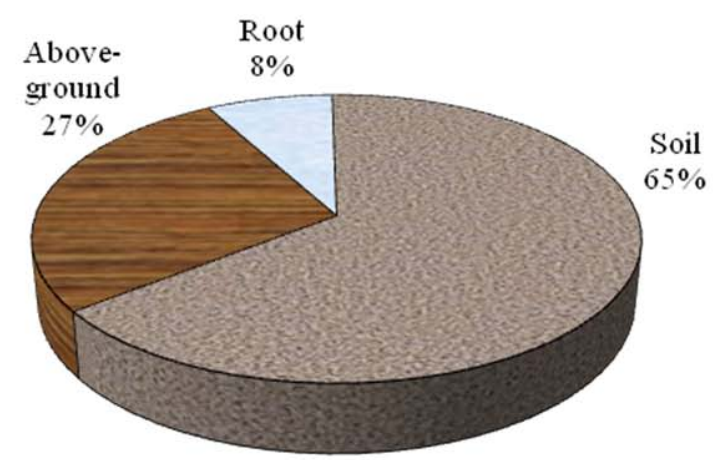

Lipindevi Thulop akho CF 
Similarly, Shrestha (2009) found total carbon pool as $178.5 \mathrm{t} \mathrm{ha}^{-1}$ which is slightly higher than the one uncovered in this study which might be due to different stand structures, site quality and intensities of management.

\section{Conclusion}

Vegetation carbon of Jarneldhara CF was found to be lower than that of Lipindevi Thulopakho CF due to the presence of smaller-size trees. The share of under-growth vegetation carbon was very low on total above-ground vegetation carbon. Soil organic carbon pool in $0-20 \mathrm{~cm}, 20-40 \mathrm{~cm}, 40-60 \mathrm{~cm}, 60-80$ $\mathrm{cm}, 80-100 \mathrm{~cm}$ soil depths were found to be different. Similarly, soil organic carbon pool in each depth of the soil profile of the two CFs were also different. With the increase in soil depth, bulk density was found to have increased whereas $C$ content was found to have decreased. Both soil organic carbon content and bulk density of Jarneldhara CF were higher than those of Lipindevi Thulopakho CF, and this contributed to the higher soil organic carbon stock in Jarneldhara CF. Total carbon stock in Jarneldhara CF was higher than in Lipindevi Thulopakho CF. On average, soil organic carbon contributed about $68 \%$ in total carbon stock of community forests. However, this study has demonstrated that CFs help to offset a portion of the carbon emissions thereby contributing to climate change amelioration through the sequestration of atmospheric $\mathrm{C}$ to soil and vegetation and by acting as a natural carbon sink.

\section{Acknowledgement}

This article is a part of the first author's M. Sc. (Forestry) thesis. The study was financially supported by Community Based Forest and Tree Management in the Himalaya (ComForM) Project, Institute of Forestry, Pokhara, Nepal.

\section{References}

Awasthi, K. D., Sitaula, B. K., Singh, B. R. and Bajracharya, R. M. 2002. Land use changes and morphometric analysis using GIS for two mountain watersheds of western Nepal. Land Degradation and Development 13: 1-19.

Banskota, K., Karky, B. S. and Dahal, N. 2008. Creating a voluntary carbon market for promoting sustainable forest management. In Shifting Paradigms in Protected Area Management (eds.) Bajracharya, S. B. and Dahal, N. National Trust for Nature Conservation, Kathmandu, Nepal, 159-170.

Baral, S. K., Malla, R. and Ranabhat, S. 2009. Aboveground carbon stock assessment in different forest types of Nepal. Banko Janakari 19 (2): $10-14$.

Brown, S., Sathaye, J., Cannell, M. and Kauppi, P. E. 1996. Mitigation of carbon emissions to the atmosphere by forest management. Commonwealth Forestry Review 75 (1): 80-91.

\section{CFD. 2004. Community Forest Resource} Inventory Guideline (Revised 2061). Nepali version Community Forest Division, Department of Forests, Kathmandu, Nepal.

DFO-Palpa. 2007. District-wise Community Forest Monitoring Report 2063/64. District Forest Office Palpa, Tansen, Nepal.

Gautam, K. R. 2002. Carbon Sequestration in Agroforestry and Annual Cropping System in Inner Terai, Central Nepal. M. Sc. Thesis. Agricultural University of Norway, Aas, Norway.

IPCC. 2007. Climate Change 2007: Synthesis Report - Summary for Policymakers. An assessment of the Intergovernmental Panel on Climate Change. Accessed from http:// www.ipcc.ch/pdf/assessment-report/ar4/syr/ ar4_syr_spm.pdf.

Lal, R. 2004. Soil carbon sequestration to mitigate climate change. Geoderma 123 (1-2): 1-22.

MacDicken, K. G. 1997. A Guide to Monitoring Carbon Storage in Forestry and Agroforestry Projects. Forest Carbon Monitoring Programme, Winrock International Institute for Agricultural Development, Littlerock, Arkansas, USA.

McLean, E. O. 1982. Soil pH and lime requirement. In Methods of Soil Analysis. Part 2, (ed.) Page, A.L. (2nd Edition), 199-224.

Negi, J. D. S., Manhas, R. K. and Chauhan, P. S. 2003. Carbon allocation in different components of some tree species of India: A new approach for carbon estimation. Current Science 85 (11): 1528-1531. 
Newell, R. G. and Stavins, R. N. 2000. Climate change and forest sinks: Factors affecting the costs of carbon sequestration. Journal of Environmental Economics and Management 40: 211-235.

Oli, B. N. and Shrestha, K. 2009. Carbon status in forests of Nepal: An overview. Journal of Forest and Livelihood 8 (1): 62-66.

Page, A. L., Reuter, D. J. and Robinson, J. B. 1982. Methods of soil analysis Part 2. Chemical and microbiological properties. Agronomy: 621-622.

Pearson, T. R., Brown, S. and Ravindranath, N. H. 2005. Integrating Carbon Benefit Estimates into GEF Projects: Guidelines. Capacity Development and Adaptation Group, Global Environment Facility, United Nations Development Programme, New York, USA.

Schreier, H., Brown, S. and Shah, P. B. 1995. Identification of key resources issues: Discussions and recommendations. In Challenges in Mountain Resource Management in Nepal: Processes, Rrends and Dynamics in Middle Mountain Watersheds. Scheier, H., Shah, P.B., and Brown, S. (eds.), ICIMOD, Kathmandu, Nepal, 247-252.

Sharma, E. R. and Pukkala, T. 1990. Volume Tables for Forest Trees of Nepal. Ministry of Forests and Soil Conservation, Forest Survey and Statistics Division, Kathmandu, Nepal.

Sharma, R. P. 2003. Relationships Between Tree Dimensions and Biomass, Sapwood Area, Leaf Area and Leaf Area Index in Alnus nepalensis D. Don in Nepal. M. Sc. Thesis. Agricultural University of Norway, Aas, Norway.

Shrestha, B. P. 2009. Carbon sequestration in SchimaCastanopsis forest: A case study from Palpa district. The Greenery (A Journal of Environment and Biodiversity), 7 (1): 34-40.
Shrestha, B. M. and Singh, B. R. 2008. Soil and vegetation carbon pools in a mountainous watershed of Nepal. Nutrient Cycling in Agroecosystems 81: 179-191.

Shrestha, B. M., Sitaula, B. K., Singh, B. R. and Bajracharya, R. M. 2004a. Fluxes of $\mathrm{CO}_{2}$ and $\mathrm{CH}_{4}$ in soil profiles of a mountainous watershed of Nepal as influenced by land use, temperature, moisture and substrate addition. Nutrient Cycling in Agroecosystems 68: 155-164.

Shrestha, B. M., Sitaula, B. K., Singh, B. R. and Bajracharya, R. M. 2004b. Soil organic carbon stocks in soil aggregates under different land use systems in Nepal. Nutrient Cycling in Agroecosystems 70: 201-213.

Sitaula, B. K., Bajracharya, R. M., Singh, B. R. and Solberg, B. 2004. Factors affecting organic carbon dynamics in soils of Nepal/ Himalayan region- a review and analysis. Nutrient Cycling in Agroecosystems 70: 215-229.

Smith, P. 2004. Carbon sequestration in croplands: The potential in Europe and the global context. European Journal of Agronomy 20 (3): 229-236.

Stern, N. 2007. The Economics of Climate Change: The Stern Review. Cambridge University Press, Cambridge, U.K.

Upadhyay, T. P., Sankhayan, P. L. and Solberg, B. 2005. A review of carbon sequestration dynamics in the Himalayan region as a function of land use change and forest/soil degradation with special reference to Nepal. Agriculture, Ecosystems and Environment 105: 449-465. 